\title{
Physicochemical and sensory properties of hamburger steak made with venison
}

\author{
Nan-Hee Lee ${ }^{1}$, Ung-Kyu Choi ${ }^{2 *}$ \\ ${ }^{I}$ Department of Medi-Food HMR Industry, Daegu Hanny University, Gyeongsan 38578, Korea \\ ${ }^{2}$ Department of Food Science \& Technology, Korea National University of Transportation, Jeungpyeong 27909, Korea
}

\section{사슴고기를 이용한 햄버거 스테이크의 이화학적 및 관능적 품질 특성}

\author{
이난희 ${ }^{1} \cdot$ 최웅규 ${ }^{2 *}$ \\ ${ }^{1}$ 대구한의대학교 메디푸드 HMR산업학과, ${ }^{2}$ 한국교통대학교 식품공학과
}

\begin{abstract}
Industrial production of processed meat products using venison requires optimization of quality attributes. In this study, physicochemical and sensory properties of hamburger steaks made with venison were evaluated. The crude protein content increased significantly but the crude fat content decteased in proportion to the venison content. The saturated fatty acid content increased as the venison content increased. Both monounsaturated fatty acids and polyunsaturated fatty acids decreased with increasing venison contents. The oleic acid content was the highest, followed by palmitic acid, stearic acid, and linoleic acid. The free amino acid content increased in proportion to the amount of venison added. The most abundant amino acids in the three types of steaks were alanine, glutamic acid, glycine and leucine. In result of sensory evaluation, the preference for hamburger steak made with $100 \%$ venison was relatively high among samples except flavor. This results confirmed that the sensory properties of hamburger steak made with venison are superior to those of pork, and thus industrialized venison production is promising.
\end{abstract}

Keywords : hamburger steak, venison, organoleptic properties, fatty acid, free amino acid

\section{서 론}

식육을 이용한 가공식품의 생산량은 육류의 소비량과 함 께 매년 지속적으로 증가하고 있는 추세에 있으며(Jeong 등, 2020), 현대인의 식탁문화에 빼놓을 수 없는 중요한 요소로 인식되고 있다(Lee 등, 2017). 지방은 육가공 식품에서 적절 한 풍미를 제공하고 긍정적인 식감을 부여하는 역할을 수행 하지만(Christiansen 등, 1975), 과도한 지방 섭취는 비만을 유발하고 고혈압, 동맥경화 및 관상동맥질환 등 만성질환의 원인이 될 수 있어(Ebbeling 등, 2002) 육가공 식품의 개발에 서 지방함량을 줄이려는 노력은 항상 중요하게 인식되어 왔
다(Kim 등, 2013).

사슴고기는 소와 돼지고기에 비해 단백질 함량이 높은 반 면, 지방 함량이 현저히 낮을 뿐만 아니라, 비타민과 미네랄 이 풍부하고 포화지방산 및 콜레스테롤 함량이 상대적으로 낮아 현대인이 추구하는 고단백, 저콜레스테롤의 조건을 갖 추고 있는 우수한 식품원료이다(Kim 등, 2005). 또한, 사슴고 기는 적색육의 비율이 높아 서양에서 건강식품으로 꾸준히 인기를 얻고 있으며, 소나 돼지고기를 뒤이은 제 3 의 동물성 식품으로 평가되어(Park 등, 2000a) 전 세계적으로 널리 사육 되어 오고 있다(Lee, 2004).

우리나라에서는 사슴사육의 목적이 녹용을 얻기 위한 것

*Corresponding author. E-mail : ukchoi@ut.ac.kr, Phone : +82-43-820-5242, Fax : +82-43-820-5240

Received 09 August 2021; Revised 06 September 2021; Accepted 13 September 2021.

Copyright (C) The Korean Society of Food Preservation.

This is an Open Access article distributed under the terms of the Creative Commons Attribution Non-Commercial License (http://creativecommons.org/licenses/by-nc/4.0) which permits unrestricted non-commercial use, distribution, and reproduction in any medium, provided the original work is properly cited. 
이므로 고기를 목적으로 하는 서구에 비해 사슴고기의 소비 가 원활하게 이루어지지 못하고 있으며, 이는 사슴사육 농가 의 소득에 악영향을 미치는 주요한 요인(Kim 등, 2020)으로 사슴사육의 목적을 녹용에서 사슴고기로 전환하여 농가소득 의 선순환구조를 가져오는 노력은 매우 시급한 과제라고 판 단된다.

햄버거스테이크는 식품산업의 발달에 따라 가정간편식 중 ready-to-heat(RTH)의 형태로 활발히 이용되고 있어 사슴고 기를 이용한 스테이크는 새로운 가정 간편식으로 충분히 활 용 가능할 것으로 판단된다(Park 등, 2004). 이에 본 연구에 서는 사슴고기를 이용하여 햄버거스테이크의 제조방법을 정 립하고 제조된 스테이크의 색도, 조지방, 조단백, 지방산 조 성, 아미노산 함량 및 관능적 특성을 확인하여 국내 사슴고기 의 육가공품 산업화를 위한 기초 자료로 제공하고자 하였다.

\section{재료 및 방법}

\section{공시재료}

본 실험에 사용된 사슴고기는 2020년 충청북도에서 도축 된 사슴고기를 청주시 소재 충북사슴영농조합법인에서 구매 하였으며, 돼지고기는 선진포크에서 구입하여 사용하였다. 그 외 실험에 사용된 시약은 모두 특급시약을 사용하였다.

\section{사슴육을 이용한 햄버거스테이크 제조}

햄버거스테이크 제조는 일반적으로 이용되는 제조방법 (Choi 등, 2016)에 따라 Fig. 1과 같이 실시하였다. 즉, 과도 한 지방과 결체조직이 제거된 원료육은 $8 \mathrm{~mm}$ plate가 장착된 글라인더(PM-114L, Manca, Barcelona, Spain)로 분쇄하였으 며, silent cutter(CN-21, Manca, Barcelona, Spain)를 이용하 여 원료육을 세절하여 사용하였다. 실험에 사용된 스테이크 의 배합비는 Table 1 과 같다. 스테이크 원료는 부재료를 첨가 하여 3 분간 혼합한 후 $12 \times 90 \mathrm{~mm}, 70 \pm 1 \mathrm{~g}$ 으로 성형한 후 $-20^{\circ} \mathrm{C}$ 에서 저장하면서 시료로 사용하였다.

\section{조단백과 조지방 함량 측정}

조단백 함량은 $\mathrm{AOAC}$ 법에 따라 Kjedahl법으로 측정하였 다(AOAC, 2005). 조지방 함량은 Min 등(1998)의 방법에 따 라 마조니아 관을 이용한 에테르 추출법을 이용하였다. 즉, $3 \mathrm{~g}$ 의 시료를 정확히 칭량하여 마조니아 관에 넣고 증류수 $11 \mathrm{~mL}$ 를 가한 다음 진한 암모니아수 $1.5 \mathrm{~mL}$ 와 $95 \%$ 에탄올 $10 \mathrm{~mL}$ 를 혼합하였다. 혼합액에 에테르를 $15 \mathrm{~mL}$ 가하여 진 탕시킨 후 석유 에테르 $15 \mathrm{~mL}$ 를 추가로 가해 혼합 후 정치시 켰다. 항량이 구해진 삼각플라스크에 마조니아관의 상등액을 여과지를 이용하여 여과한 후 동일한 과정을 2-3회 반복하여

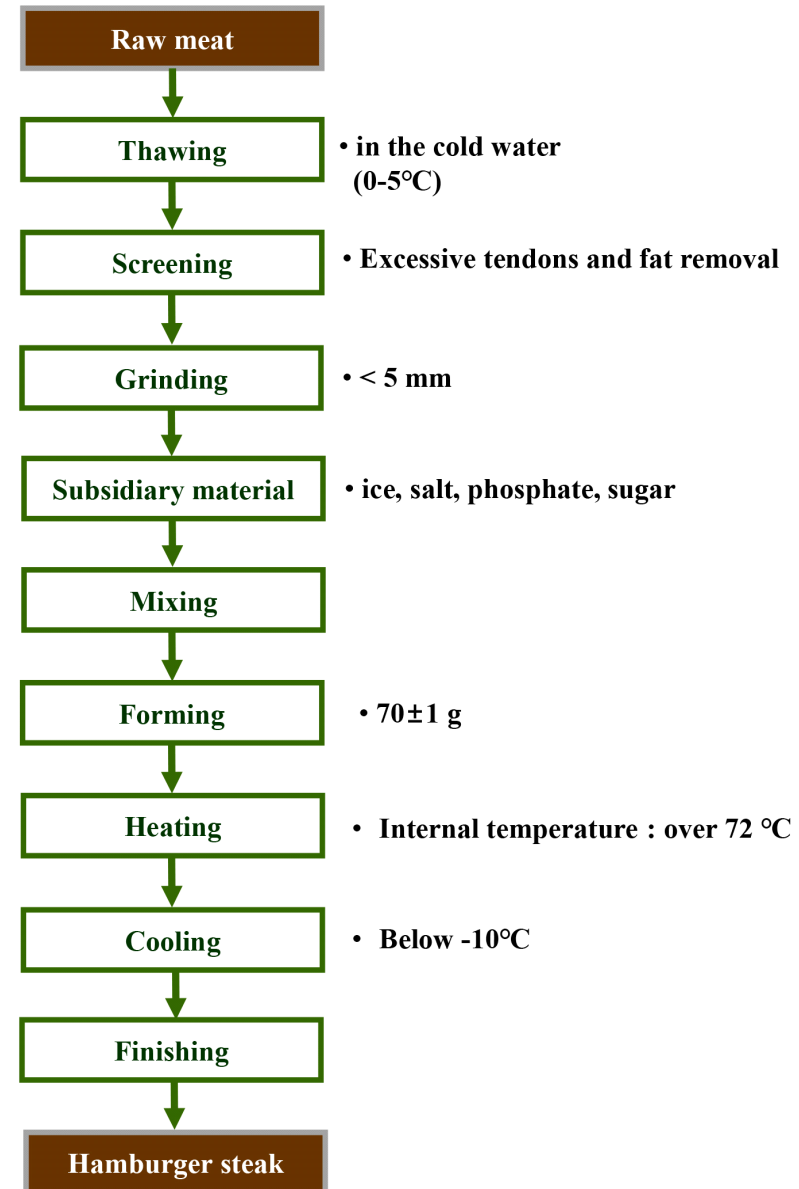

Fig. 1. Procedure for preparation of the hamburger steak made with venison.

Table 1. Formulations of hamburger steak made with venison

(unit: \%)

\begin{tabular}{ccccc}
\hline \multirow{2}{*}{ Ingredients } & \multicolumn{3}{c}{ Hamburger steak } \\
\cline { 3 - 5 } & Pork hind leg & 100 & 50 & 0 \\
\hline \multirow{3}{*}{ Meat } & Venison & 0 & 50 & 100 \\
\cline { 2 - 5 } & Total & 100 & 100 & 100 \\
\hline \multirow{3}{*}{ Others } & Ice & 10 & 10 & 10 \\
& Salt & 0.5 & 0.5 & 0.5 \\
& Phosphate & 0.3 & 0.3 & 0.3 \\
& Sugar & 1.0 & 1.0 & 1.0 \\
\hline
\end{tabular}

${ }^{1)} \mathrm{HPP}$, hamburger steaks made with pork.

${ }^{2} \mathrm{HPV}$, hamburger steaks made with pork and venison (50:50).

${ }^{3)} \mathrm{HVV}$, hamburger steaks made with venison. 
모은 상등액을 water bath $\left(75^{\circ} \mathrm{C}\right)$ 에서 증발건조시킨 후 드라 이오븐 $\left(60^{\circ} \mathrm{C}\right)$ 에서 건조시켜 항량을 구하였다.

\section{지방산 조성 분석}

지방산 함량 분석을 위해서 소시지 시료 $10 \mathrm{~g}$ 에 클로로포 름과 메탄올을 2:1(v/v)로 혼합한 용매 $150 \mathrm{~mL}$ 를 넣고 3분 동안 2,500 $\times g$ 에서 균질기로 마쇄한 다음 여과지(Whatman No. 1)로 여과하였다. 여과액에 다시 클로로포름과 메탄올 혼합 유기용매 $100 \mathrm{~mL}$ 를 넣어 재차 마쇄 후 용출시키고, 이 여액에 증류수를 총 여액에 대하여 $1 / 3$ 정도 되게 첨가하여 균형을 맞추고, $3,000 \times g$ 에서 10 분간 원심분리하여 하층액 을 지방산 분석의 시료로 사용하였다. 이때 하층액을 여과하 되, 남은 수분은 $\mathrm{Na}_{2} \mathrm{SO}_{4}$ 를 이용하여 흡착 여과하였다. 이렇게 얻어진 여액을 농축기(Rotary evaporator, N-1000, Eyela, Tokyo, Japan)를 이용하여 $560-565^{\circ} \mathrm{C}$ 사이에서 농축하고, 농 축된 지질은 질소가스를 주입한 후 parafilm으로 밀봉하며, methylation까지 $-20^{\circ} \mathrm{C}$ 에서 냉동 보관하였다. 지방질 시료 $4-10 \mathrm{mg}$ 을 $0.5 \mathrm{~N} \mathrm{NaOH}$ 용액 $1 \mathrm{~mL}$ 를 가하여 밀봉한 다음 $90^{\circ} \mathrm{C}$ 에서 30 분간 가열하여 냉각한 후 다시 $2 \mathrm{~mL} \mathrm{BF}_{3}$-methanol 을 넣고, $90^{\circ} \mathrm{C}$ 에서 30 분간 가열한 후 $0.5 \mathrm{~mL}$ 를 취하였다. 여 기에 $1 \mathrm{~mL}$ 의 heptane을 가하고 충분히 흔든 후 $2 \mathrm{~mL}$ 의 포화 $\mathrm{NaCl}$ 용액을 가하여 1 분간 혼합한 다음 30 분간 방치하였다. 이렇게 얻어진 상층액 $0.5 \mu \mathrm{L}$ 를 취하여 gas chromatography (Agilent 7890, Agilent, Santa Clara, CA, USA)로 분석하였 다. $\mathrm{GC}$ 의 컬럼은 $\mathrm{HP}-\mathrm{INNOWAX}(30 \mathrm{~m} \times 0.25 \mathrm{~nm} \mathrm{ID}, 0.25$ $\mu \mathrm{m}$ film) (Agilent 7890, Agilent, Santa Clara, CA, USA), 검출기 온도는 $260^{\circ} \mathrm{C}$, 주입기 온도는 $260^{\circ} \mathrm{C}$, 오븐 온도는 $100^{\circ} \mathrm{C} / 2 \mathrm{~min}-3^{\circ} \mathrm{C} / \mathrm{min}-230^{\circ} \mathrm{C} / 20 \mathrm{~min}$ 으로 하였고, 운반기체는 질소를 사용하였다.

\section{유리아미노산 함량 측정}

$200 \mathrm{~g}$ 의 시료를 $800 \mathrm{~mL}$ 의 Et-OH에 넣고 $85^{\circ} \mathrm{C}$ 에서 2시간 동안 환류추출한 후 여과액을 감압 건조하여 얻은 건조시료 에 3차 증류수를 첨가하여 $100 \mathrm{~mL}$ 로 정용한 다음 amberlite IR-118H와 amberlite IRA-400(Sigma-Aldrich, St. Louis, $\mathrm{MO}, \mathrm{USA})$ 이 각각 충전된 칼럼 $(25 \mathrm{~cm} \times 4.6 \mathrm{~mm})$ 에 연속 통 과시켰다. 양이온 교환수지에 흡착된 아미노산은 $5 \%$ $\mathrm{NH}_{4} \mathrm{OH}$ 용액 $300 \mathrm{~mL}$ 로 용출시켜 감압농축한 후, $0.2 \mathrm{~N}$ sodium citrate $(\mathrm{pH} 2.2)$ 로 5 배 희석한 다음, 여과지 $(0.2 \mu \mathrm{m})$ 로 여과한 액 $20 \mu \mathrm{L}$ 를 아미노산 자동 분석기(Bio chrom $30 \mathrm{amino}$ acid analyzer, Amersham bioscience, London, UK)로 분석하 였다. Sodium citrate buffer의 유속은 $35 \mathrm{~mL} / \mathrm{h}$, ninhydrin의 유속은 $25 \mathrm{~mL} / \mathrm{h}$, 온도 기울기는 $46,50,95$ 및 $46^{\circ} \mathrm{C}$, 분석파
장은 $440 \mathrm{~nm}$ 와 $570 \mathrm{~nm}$, 칼럼은 cation exchange resin을 분 석에 사용하였다.

\section{관능검사}

사슴고기를 이용하여 제조한 햄버거스테이크의 관능적 품 질 평가를 조사하기 위해 관능 검사 요원 10 명을 선정하여 충분히 가열 처리한 스테이크를 $\varnothing 30 \mathrm{~mm}$ 크기로 제시하여 기호도에 대한 관능검사를 9점 척도법으로 실시하였다. 그 기준은 굉장히 좋다(9점), 매우 좋다(8점), 좋다(7점), 약간 좋 다(6점), 보통이다(5점), 약간 싫다(4점), 싫다(3점), 매우 싫 다(2점), 굉장히 싫다(1점)로 평가하고, 평균과 표준편차로 나타내었다. 이 때 시료의 순서는 무작위로 배치하였으며, 각 시료에는 난수표에서 추출한 세 자리 숫자를 임의로 표시하 여 검사의 오류를 방지하였다(IRB 승인번호: KNUT IRB 2021-4).

\section{통계처리}

모든 실험은 3회 반복 측정하여 평균과 표준편차로 나타내 었으며, 실험결과에 대한 통계 처리는 SPSS software package (Statistical Package for Social Sciences, version 12, SPSS Inc., Chicago, IL, USA)를 이용하여 one-way ANOVA로 유 의성을 검증하고, Duncan's multiple range test를 이용하여 유의수준 $\mathrm{p}<0.05$ 에서 유의성을 검정하였다.

\section{결과 및 고찰}

\section{조단백과 조지방 함량}

원료육을 달리하여 제조한 햄버거스테이크의 조단백 함량 을 확인한 결과는 Fig. 2(A)에 나타낸 바와 같이 사슴고기의 첨가에 비례하여 유의적인 증가패턴을 보이는 것을 확인할 수 있었다. 즉, 사슴고기를 사용한 스테이크(이하 HVV)의 조 단백 함량이 $18.2 \pm 0.2 \%$ 로 가장 높았으며, 사슴과 소고기를 혼합하여 제조한 스테이크(HPV: $17.8 \pm 0.2 \%$ )와 돼지고기로 제조한 스테이크(HPP: $17.2 \pm 0.2 \%)$ 의 순으로 확인되었다. 조 지방 함량은 Fig. 2(B)에 나타낸 바와 같다. HPP의 조지방 함 량은 $4.6 \pm 0.1 \%$ 로 나타났으며, $\mathrm{HPV}$ 와 PVV는 각각 $3.9 \pm 0.2 \%$ 와 $3.1 \pm 0.3 \%$ 로 나타나, 사슴고기의 첨가에 비례하여 유의적 인 감소패턴을 보이는 것을 확인할 수 있었다( $\mathrm{p}<0.05)$. 이러 한 결과는 실험에 사용된 돼지와 사슴고기의 일반성분 조성 비의 차이에 기인하는 것으로 사슴고기의 조단백 함량 $(22.9 \%)$ 이 돼지고기의 조단백 함량 $(18.5 \%)$ 보다 $4.4 \% \mathrm{P}$ 높은 반면, 사슴고기의 조지방 함량( $2.4 \%)$ 은 돼지고기의 조지방 함량 $(16.5 \%)$ 에 비해 $14.1 \% \mathrm{P}$ 낮기 때문(Park 등, $2000 \mathrm{a})$ 인 것 으로 판단된다. 
(A)

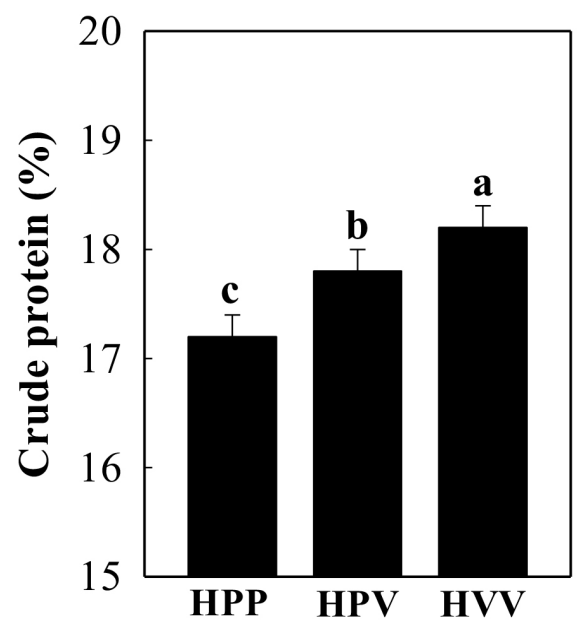

(B)

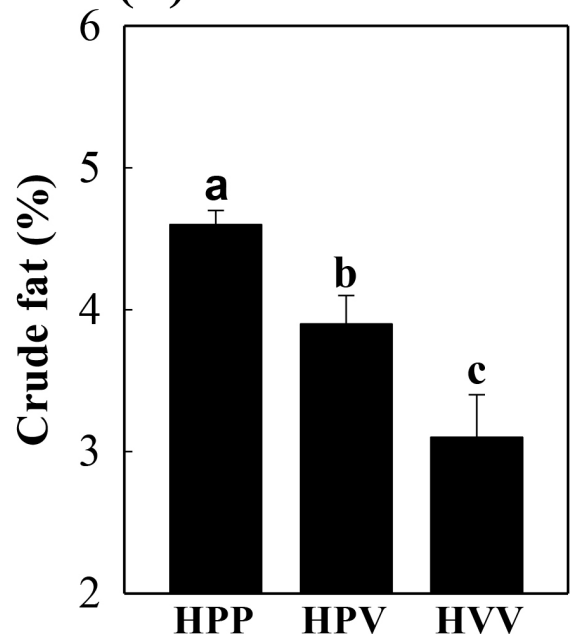

Fig. 2. The content of crude protein and crude fat in the hamburger steak made with venison.

HPP, hamburger steaks made with pork; HPV, hamburger steaks made with pork and venison (50:50); HVV, hamburger steaks made with venison.

Different superscripts indicate significant difference at $\mathrm{p}<0.05$ by Duncan's multiple range test. Values are means \pm standard deviations of triplicate determinations.

\section{지방산 조성}

원료육을 달리하여 제조한 햄버거스테이크의 지방산 조성 을 확인한 결과는 Table 2에 나타내었다. 지방산 조성은 지방 함량을 100 으로 본 후 각종 지방산의 조성비를 구한 것으로 절대적 지방함량과는 차이를 보인다. 지방산은 포화지방산 5 종, 단일불포화지방산 4 종, 다가불포화지방산 3 종 등 총 12 종이 분석되었다. 포화지방산 함량은 HVV에서 $47.57 \%$ 로 가
Table 2. The fatty acid composition of hamburger steak made with venison

(unit: \%)

\begin{tabular}{|c|c|c|c|c|}
\hline \multirow{2}{*}{\multicolumn{2}{|c|}{ Fatty acid }} & \multicolumn{3}{|c|}{ Hamburger steak } \\
\hline & & $\mathrm{HPP}^{1)}$ & $\mathrm{HPV}^{2)}$ & $\mathrm{HVV}^{3)}$ \\
\hline \multirow{6}{*}{$\mathrm{SFA}^{4)}$} & $\mathrm{C} 12: 0$ & $0.22 \pm 0.00^{\mathrm{a}}$ & $0.16 \pm 0.00^{b}$ & $0.16 \pm 0.01^{\mathrm{b}}$ \\
\hline & C14:0 & $1.98 \pm 0.00^{\mathrm{c}}$ & $2.72 \pm 0.00^{\mathrm{b}}$ & $3.35 \pm 0.00^{\mathrm{a}}$ \\
\hline & C16:0 & $24.12 \pm 0.01^{\mathrm{c}}$ & $25.55 \pm 0.00^{\mathrm{b}}$ & $26.77 \pm 0.01^{\mathrm{a}}$ \\
\hline & C18:0 & $9.18 \pm 0.01^{\mathrm{c}}$ & $16.41 \pm 0.01^{\mathrm{b}}$ & $17.11 \pm 0.01^{\mathrm{a}}$ \\
\hline & $\mathrm{C} 20: 0$ & $0.18 \pm 0.01$ & $0.18 \pm 0.01$ & $0.18 \pm 0.01$ \\
\hline & Subtotal & $35.68 \pm 0.01^{\mathrm{c}}$ & $45.02 \pm 0.01^{\mathrm{b}}$ & $47.57 \pm 0.01^{\mathrm{a}}$ \\
\hline \multirow{5}{*}{ MUFA $^{5)}$} & C14:1 & $0.02 \pm 0.00^{\mathrm{c}}$ & $0.82 \pm 0.01^{b}$ & $1.99 \pm 0.00^{\mathrm{a}}$ \\
\hline & $\mathrm{C} 16: 1$ & $3.12 \pm 0.00^{\mathrm{c}}$ & $5.57 \pm 0.00^{\mathrm{b}}$ & $7.21 \pm 0.00^{\mathrm{a}}$ \\
\hline & C18:1 & $43.12 \pm 0.01^{\mathrm{a}}$ & $33.99 \pm 0.01^{\mathrm{b}}$ & $29.11 \pm 0.01^{\mathrm{c}}$ \\
\hline & C20:1 & $1.12 \pm 0.00^{\mathrm{a}}$ & $0.33 \pm 0.00^{\mathrm{b}}$ & $0.31 \pm 0.00^{\mathrm{c}}$ \\
\hline & Subtotal & $47.38 \pm 0.01^{\mathrm{a}}$ & $40.71 \pm 0.01^{\mathrm{b}}$ & $38.62 \pm 0.01^{\mathrm{c}}$ \\
\hline \multirow{4}{*}{ PUFA $^{6}$} & $\mathrm{C} 18: 2$ & $11.65 \pm 0.01^{\mathrm{a}}$ & $9.74 \pm 0.01^{\mathrm{b}}$ & $9.54 \pm 0.01^{\mathrm{c}}$ \\
\hline & C18:3 & $0.66 \pm 0.00^{\mathrm{a}}$ & $0.47 \pm 0.00^{\mathrm{b}}$ & $0.40 \pm 0.00^{\mathrm{b}}$ \\
\hline & $\mathrm{C} 20: 2$ & $0.45 \pm 0.00^{\mathrm{a}}$ & $0.11 \pm 0.00^{b}$ & $0.11 \pm 0.00^{b}$ \\
\hline & Subtotal & $12.76 \pm 0.01^{\mathrm{a}}$ & $10.32 \pm 0.01^{\mathrm{b}}$ & $10.05 \pm 0.01^{\mathrm{c}}$ \\
\hline \multicolumn{2}{|c|}{ Total } & $95.82 \pm 0.01^{\mathrm{c}}$ & $96.05 \pm 0.01^{\mathrm{b}}$ & $96.24 \pm 0.01^{\mathrm{a}}$ \\
\hline
\end{tabular}

${ }^{1)} \mathrm{HPP}$, hamburger steaks made with pork.

${ }^{2)} \mathrm{HPV}$, hamburger steaks made with pork and venison (50:50).

${ }^{3)} \mathrm{HVV}$, hamburger steaks made with venison.

${ }^{4)}$ SFA, saturated fatty acid.

${ }^{5)}$ MUFA, mono unsaturated fatty acid.

${ }^{6}$ )PUFA, poly unsaturated fatty acid.

Different superscripts indicate significant difference at $\mathrm{p}<0.05$ by Duncan's multiple range test. Values are means \pm standard deviations of triplicate determinations.

장 높았으며, $\operatorname{HPV}(45.02 \pm 0.01 \%), \operatorname{HPP}(35.68 \pm 0.01 \%)$ 의 순 으로 나타나 사슴고기의 함량의 증가에 비례하여 포화지방산 함량도 높아짐을 확인할 수 있었다. 단일불포화지방산과 다 가 불포화지방산의 함량은 모두 사슴고기의 함량이 증가함에 따라 낮아지는 것을 확인되었다. 지방산의 종류별로는 oleic $\operatorname{acid}(\mathrm{C} 18: 1)$ 의 함량이 가장 높았으며, palmitic $\operatorname{acid}(\mathrm{C} 16: 0)$, stearic $\operatorname{acid}(\mathrm{C} 18: 0)$ 및 linoleic $\operatorname{acid}(\mathrm{C} 18: 2)$ 순으로 많이 함유 되어 있었다. 포화지방산의 함량은 모든 시료에서 palmitic acid, stearic acid 및 myristic acid(C14:0)의 순으로 함량이 높 았으며, 세 지방산 모두 사슴고기의 함량에 비례하여 증가하 는 패턴을 보였다. 단일불포화지방산은 oleic acid, palmitoleic acid의 순으로 많이 함유되어 있는 것으로 나타났으며, oleic acid는 사슴고기의 첨가량이 증가함에 따라 함량이 감소하였 으나, palmitoleic acid는 반대의 패턴을 보였다. 다가 불포화 
지방산은 linoleic acid가 전 시험구에서 가장 많이 함유되어 있었으며, 그 함량은 HPP, HPV 및 HVV가 각 $11.65 \pm 0.01 \%$, $9.74 \pm 0.01 \%$ 및 $9.54 \pm 0.01 \%$ 로 나타났다. 김 등( 2020$)$ 은 사슴 고기를 첨가하여 소시지를 제조한 후 지방산 조성을 확인한 결과, 포화지방산이 사슴고기의 함량에 비례하여 증가하였으 며, 단일불포화지방산과 다가불포화지방산은 사슴육 함량에 반비례하는 패턴을 보인 것으로 본 연구와 유사한 결과를 보 고한 바 있다.

\section{유리아미노산 함량}

원료육을 달리하여 제조한 햄버거스테이크의 유리아미노 산 조성을 확인한 결과는 Table 3에 나타내었다. 유리아미노 산은 17종이 분석되었으며, 총 유리아미노산 함량은 $\mathrm{HVV}$ 에 서 $125.0 \pm 4.9 \mathrm{mg} \%$ 로 가장 높게 나타났으며, $\mathrm{HPV}(101.2 \pm 4.0$ $\mathrm{mg} \%)$ 및 $\mathrm{HPP}(80.8 \pm 3.1 \mathrm{mg} \%)$ 의 순으로 나타나, 유리아미노 산의 함량은 사슴고기의 첨가량에 비례하여 높아지는 것으로 확인되었다. 돼지고기를 주원료로 한 HPP에서 가장 많이 함 유된 아미노산은 alanine, glutamic acid, glycine 및 leucine의 순이었으며, HPV와 HVV에서도 HPP와 유사한 결과가 확인 되었다. 이는 돼지고기 중에 많이 존재하는 유리아미노산이 알라닌, 글리신 및 글루탐산이라고 한 보고(Ewan 등, 1979; Lakritz 등, 1976)와 유사한 결과이다. 본 연구에서는 단맛 성 분(threonine, glycine, serine, alanine 및 lysine), 구수한 맛 성분 (glutamic acid, aspartic acid, cystein), 쓴맛 성분(isoleucine, leucine, methionine) 및 기타 성분(arginine, proline, phenylalanine, valine, tyrosine, histidine 및 tryptophan)으로 구분하여 함량 을 비교하였다(Choi 등, 2011). 단맛, 구수한 맛, 쓴맛 및 기 타 성분 모두 HVV에서 가장 높게 나타났으며, HPV와 HPP 의 순으로 나타났고, 이는 사슴고기와 소고기의 단백질 함량 이 돼지고기에 비해 높았기 때문인 것으로 판단된다. 김 등은 사슴고기를 첨가하여 제조한 소시지의 유리아미노산 함량은 사슴고기의 함량에 비례하여 높아졌으며, 필수아미노산의 함 량도 돈육 소시지보다 높다고 본 연구와 유사한 결과를 보고 한 바 있다. 이는 박 등(2000b)은 사슴고기가 다른 식육과 비 교하여 단백질 함량이 높으며, 필수아미노산의 함량과 비율 도 상대적으로 높다는 보고와도 일치하는 것이다.

\section{관능검사}

원료육을 달리하여 제조한 햄버거스테이크의 외관, 항기, 조직감, 맛 및 종합적 기호도에 대하여 관능검사를 실시한 결 과는 Table 4에 나타낸 바와 같다. 주원료로 사슴고기를 이용 한 햄버거 스테이크(HPV와 HVV)에 대한 선호도가 모든 측 정항목에서 가장 높았으며, 돼지고기를 주원료로 제조한 햄 버거 스테이크의 기호도가 외관을 제외한 모든 항목에서 가
Table 3. Free amino acid of hamburger steak made with venison (unit: $\mathrm{mg} \%$ )

\begin{tabular}{|c|c|c|c|c|}
\hline \multirow{2}{*}{\multicolumn{2}{|c|}{ Free amino acid }} & \multicolumn{3}{|c|}{ Hamburger steak } \\
\hline & & $\mathrm{HPP}^{1)}$ & $\mathrm{HPV}^{2)}$ & $\mathrm{HVV}^{3)}$ \\
\hline \multirow{6}{*}{$\begin{array}{l}\text { Sweet } \\
\text { taste }\end{array}$} & Thr & $4.2 \pm 0.3^{\mathrm{c}}$ & $4.6 \pm 0.2^{b}$ & $6.0 \pm 0.3^{\mathrm{a}}$ \\
\hline & Ser & $4.3 \pm 0.3^{\mathrm{b}}$ & $4.0 \pm 0.1^{\mathrm{b}}$ & $7.9 \pm 0.2^{\mathrm{a}}$ \\
\hline & Gly & $7.7 \pm 0.3^{\mathrm{c}}$ & $9.8 \pm 0.3^{\mathrm{b}}$ & $10.9 \pm 0.2^{\mathrm{a}}$ \\
\hline & Ala & $18.2 \pm 1.1^{\mathrm{c}}$ & $28.1 \pm 1.0^{\mathrm{a}}$ & $28.8 \pm 0.8^{\mathrm{a}}$ \\
\hline & Lys & $3.4 \pm 0.2^{\mathrm{b}}$ & $3.4 \pm 0.1^{\mathrm{b}}$ & $5.6 \pm 0.4^{\mathrm{a}}$ \\
\hline & Subtotal & $37.8 \pm 1.2^{\mathrm{c}}$ & $49.9 \pm 1.7^{b}$ & $59.2 \pm 1.9^{\mathrm{a}}$ \\
\hline \multirow{4}{*}{$\begin{array}{c}\text { Savory } \\
\text { taste }\end{array}$} & Asp & $0.5 \pm 0.0^{\mathrm{c}}$ & $1.3 \pm 0.1^{\mathrm{b}}$ & $2.5 \pm 0.2^{\mathrm{a}}$ \\
\hline & Glu & $9.6 \pm 0.4^{\mathrm{c}}$ & $12.3 \pm 0.2^{\mathrm{b}}$ & $12.9 \pm 0.5^{\mathrm{a}}$ \\
\hline & Cys & $0.2 \pm 0.1^{\mathrm{a}}$ & $0.2 \pm 0.0^{\mathrm{a}}$ & $0.1 \pm 0.0^{b}$ \\
\hline & Subtotal & $10.3 \pm 0.5^{\mathrm{c}}$ & $13.8 \pm 0.3^{\mathrm{b}}$ & $15.5 \pm 0.7^{\mathrm{a}}$ \\
\hline \multirow{4}{*}{$\begin{array}{l}\text { Bitter } \\
\text { taste }\end{array}$} & Met & $2.3 \pm 0.1^{\mathrm{c}}$ & $3.0 \pm 0.2^{\mathrm{b}}$ & $4.3 \pm 0.2^{\mathrm{a}}$ \\
\hline & Ile & $2.7 \pm 0.1^{\mathrm{c}}$ & $3.6 \pm 0.1^{\mathrm{b}}$ & $4.1 \pm 0.3^{\mathrm{a}}$ \\
\hline & Leu & $6.9 \pm 0.2^{\mathrm{c}}$ & $7.4 \pm 0.5^{\mathrm{b}}$ & $9.2 \pm 0.3^{\mathrm{a}}$ \\
\hline & Subtotal & $11.9 \pm 0.4^{\mathrm{c}}$ & $14.0 \pm 0.8^{\mathrm{b}}$ & $17.6 \pm 0.8^{\mathrm{a}}$ \\
\hline \multirow{7}{*}{ Others } & Pro & $2.7 \pm 0.1^{\mathrm{b}}$ & $2.6 \pm 0.1^{\mathrm{b}}$ & $4.7 \pm 0.1^{\mathrm{a}}$ \\
\hline & Val & $4.3 \pm 0.3^{\mathrm{c}}$ & $5.1 \pm 0.3^{\mathrm{b}}$ & $6.4 \pm 0.2^{\mathrm{a}}$ \\
\hline & Tyr & $3.7 \pm 0.2^{\mathrm{a}}$ & $3.4 \pm 0.2^{\mathrm{b}}$ & $3.3 \pm 0.4^{b}$ \\
\hline & Phe & $3.1 \pm 0.1^{\mathrm{c}}$ & $4.0 \pm 0.2^{\mathrm{b}}$ & $5.6 \pm 0.3^{\mathrm{a}}$ \\
\hline & His & $2.6 \pm 0.2^{\mathrm{c}}$ & $3.5 \pm 0.2^{\mathrm{b}}$ & $4.0 \pm 0.2^{\mathrm{a}}$ \\
\hline & Arg & $4.4 \pm 0.1^{\mathrm{c}}$ & $5.1 \pm 0.2^{\mathrm{b}}$ & $8.6 \pm 0.3^{\mathrm{a}}$ \\
\hline & Subtotal & $20.8 \pm 1.0^{\mathrm{c}}$ & $23.7 \pm 1.2^{\mathrm{b}}$ & $32.6 \pm 1.5^{\mathrm{a}}$ \\
\hline \multicolumn{2}{|c|}{ Total } & $80.8 \pm 3.1^{\mathrm{c}}$ & $101.2 \pm 4.0^{\mathrm{b}}$ & $125.0 \pm 4.9^{a}$ \\
\hline
\end{tabular}

${ }^{1)} \mathrm{HPP}$, hamburger steaks made with pork.

${ }^{2)} \mathrm{HPV}$, hamburger steaks made with pork and venison (50:50).

${ }^{3} \mathrm{HVV}$, hamburger steaks made with venison.

Different superscripts in a row indicate significant difference at $p<0.05$ by Duncan's multiple range test. Values are means \pm standard deviations of triplicate determinations.

장 낮은 것으로 확인되었다. 향기는 세 종류의 스테이크 사이 에서 유의적인 차이가 없는 것으로 나타났다. 사슴고기 또는 사슴고기를 혼합한 햄버거스테이크에 대한 관능적 특성을 비 교한 연구는 현재까지 보고되어 있지 않으며, 사슴육과 돈육 으로 제조한 소시지의 관능적 특성을 비교한 연구(Kim 등, 2020)에서 사슴육의 첨가는 소시지의 유리아미노산과 필수 아미노산의 함량을 증가시켰으며, 관능검사에서 맛과 조직감 및 종합적 기호도를 개선한다고 보고한 바 있다. 또한, 햄버 
Table 4. Sensory evaluation score of hamburger steak made with venison

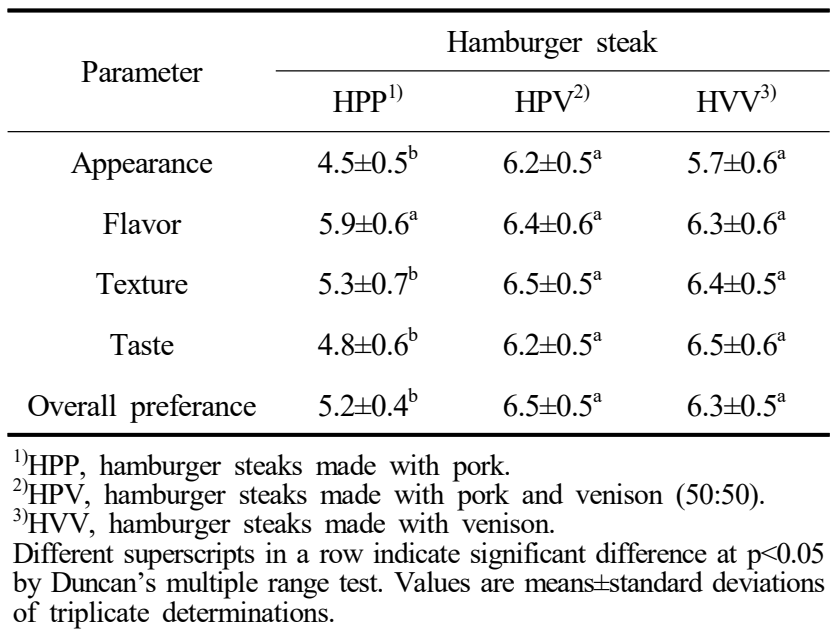

거 패티 제조시 머리고기를 $10 \%$ 이하로 첨가할 경우, 햄버거 패티의 품질과 관능적으로 우수한 제품을 제조할 수 있는 것 으로 보고된 바 있다(Choi 등, 2016). 조리 후 제품의 수분함 량과 물성에 관한 연구는 추가로 진행되어야 할 것으로 판단 되며, 본 연구 결과에서 사슴 고기로 제조한 햄버거스테이크 는 관능적 특성이 돼지고기에 비해 관능적 특성이 우수한 것 으로 확인되어 산업화 전망이 밝을 것으로 기대된다.

\section{요 약}

본 연구에서는 사슴고기를 이용하여 제조한 햄버거스테이 크의 조지방, 조단백, 지방산 조성, 아미노산 함량 및 관능적 특성을 확인하여 사슴고기를 이용한 육가공품 산업화를 위한 기초 자료로 제공하고자 하였다. 지방산은 포화지방산 5 종, 단일불포화지방산 4 종, 다가불포화지방산 3 종 등 총 12 종이 분석되었다. 포화지방산 함량은 사슴고기의 함량의 증가에 비례하여 높아졌다. 단일불포화지방산과 다가 불포화지방산 의 함량은 모두 사슴고기의 함량이 증가함에 따라 낮아졌다. 지방산의 종류별로는 올레산의 함량이 가장 높았으며, 팔미 트산, 스테아르산 및 리놀레산의 순으로 많이 함유되어 있었 다. 유리아미노산의 함량은 사슴고기의 첨가량에 비례하여 높아졌으며, 세 가지 스테이크에서 가장 많이 함유된 아미노 산은 alanine, glutamic acid, glycine 및 leucine의 순이었다. 단맛, 구수한 맛, 쓴맛 및 기타 성분 모두 HVV에서 가장 높 게 나타났으며, HPV와 HPP의 순으로 나타났다. 관능검사 결과, 향기를 제외한 모든 항목에서 사슴고기를 이용한 햄버 거 스테이크(HPV와 HVV)에 대한 선호도가 HVV보다 높게 나타났다. 향기는 세 종류의 스테이크 사이에서 유의적인 차 이가 없는 것으로 나타났다. 본 연구 결과에서 사슴 고기로
제조한 햄버거스테이크는 관능적 특성이 돼지고기에 비해 관 능적 특성이 우수한 것으로 확인되어 산업화 전망이 밝을 것 으로 기대된다.

\section{Conflict of interests}

The authors declare no potential conflict of interest.

\section{ORCID}

Nan-Hee Lee https://orcid.org/0000-0002-7549-0628

Ung-Kyu Choi https://orcid.org/0000-0002-4551-8693

\section{References}

AOAC. Official Method of Analysis of AOAC International. 18th ed, Association of Official Analytical Chemists, Aplington, VA, USA, p 3-36 (2005)

Choi UK, Jeong YS, Kwon OJ, Park JD, Kim YC. Comparative study of quality characteristics of Korean soy sauce made with soybeans germinated under dark and light conditions. Int $\mathrm{J}$ Mol Sci, 12, 8105-8118 (2011)

Choi YS, Jeon KH, Ku SK, Sung JM, Choi HW, Seo DH, Kim CJ, Kim YB. Quality characteristics of replacing pork hind leg with pork head meat for hamburger patties. Korean J Food Cook Sci, 32, 58-64 (2016)

Christiansen LN, Tompkin RB, Shaparis AB, Johnston RW, Kautter DA. Effect of sodium nitrite and nitrate on Clostridium botulinum growth and toxin production in a summer style sausage. J Food Sci, 40, 488-490 (1975)

Ebbeling CV, Pawlak DB, Ludwig DS. Childhood obesity: Public-health crisis, common sense cure. Lancet, 360, 473-482 (2002)

Ewan RC, Topel DG, Ono K. Chemical composition of chops from pale soft exudative (PSE) and normal pork loins. J Food Sci, 44, 678-680 (1979)

Jeong HG, Jo K, Lee S, Choi YS, Jeong S. Substitution of phosphate and ISP by Allomyrina dichotoma larvae powder in emulsion sausage. Ann Anim Resour Sci, 31, 134-144 (2020)

Kim HA, Kim BC, Kim YK. Quality characteristics of the sausages added with pepper seed powder and pepper seed oil. Korean J Food Cookery Sci, 29, 283-289 
(2013)

Kim IS, Jin SK, Hah KH, Park ST, Kwuak KR, Park JK, Kang YS, Chung KY. Changes of in vacuum packed pre-aged venison with seasoning during chilled storage. Korean J Food Sci Anim Resour, 25, $442-448$ (2005)

Kim JU, Baek GG, Lee NH, Choi WS, Choi UK. Organoleptic characteristics of Frankfurter sausage made with venison. Korean J Food Nutr, 33, 639-644 (2020)

Lakritz L, Spinelli AM, Wasserman AE. Effect of storage on the concentration of proline and other free amino acids in pork bellies. J Food Sci, 41, 879-881 (1976)

Lee GW. Physico-chemical properties and composition of venison in deer breeds. J Life Sci, 14, 525-530 (2004)

Lee NR, Joo JY, Yeo YH. Use of real-time PCR and internal standard addition method for identifying mixed ratio of chicken meat in sausages. J Korean Soc food Sci Nutr, 46, 1097-1105 (2017)

Park CI, Kim YJ, Kim Y, Kim DJ, Yu BV, Ahn J. Studies on chemical composition, amino acid, minerals of venison. J East Asian Soc Diet Life, 10, 222-228 (2000b)

Park CI, Kim YK, Kim YJ. Effect of vacuum packaging and aerobic packaging on the physico-chemical characteristics of venison. Korean J Food Sci Anim Resour, 20, 214221 (2000a)

Park KS, Kim JG, Lee WJ, Oh SH, Lee YS, Kim JH, Kim JH, Kim WG, Byun MW. Effect of combined treatment of gamma irradiation and addition of rosemary extract powder on ready-to-eat hamburger steaks. J Korean Soc Food Sci Nutr, 33, 694-699 (2004) 